\title{
Validation and cross-cultural adaptation of sexual dysfunction modified scale in multiple sclerosis for Brazilian population
}

\author{
Validação e adaptação transcultural da escala modificada de disfunção sexual em \\ esclerose múltipla na população brasileira \\ Raquel Ataide Peres da Silva, Guilherme Sciascia do Olival, Livia Palma Stievano, Vania Balardin Toller, \\ Sergio Semeraro Jordy, Marina Eloi, Charles Peter Tilbery
}

\begin{abstract}
Multiple sclerosis (MS) is a chronic inflammatory disease of the central nervous system (CNS). These patients suffer from various comorbidities, including sexual dysfunction (SD). The lesions of MS may affect regions of the CNS along the pathway of sexual response. The Multiple Sclerosis Intimacy and Sexuality Questionnaire-19 (MSISQ-19) is a scale that assesses sexual dysfunction. Objectives: Adapt and validate the MSISQ-19 to Brazilian patients with MS. 204 individuals were evaluated, 134 patients with MS and 70 healthy persons for the control group. It was determined reproducibility, validity, internal consistency and sensitivity of the MSISQ-19-BR. Among patients with MS, $54.3 \%$ of male and $71.7 \%$ of female presented some kind of SD. In the control group the results were $12.5 \%$ and $19.5 \%$, respectively. The MSISQ-19-BR is reproducible, reliable and valid for the Brazilian population and may be used as a tool for assessing the impact of sexual dysfunction in patients with MS.
\end{abstract}

Keywords: sexual dysfunction, multiple sclerosis, questionnaires.

\section{RESUMO}

A esclerose múltipla (EM) é uma doença crônica inflamatória do sistema nervoso central (SNC). Esses pacientes sofrem de várias comorbidades, incluindo a disfunção sexual. As lesões da EM podem afetar varias regiões do SNC inclusive a via de resposta sexual. 0 Multiple Sclerosis Intimacy and Sexuality Questionnaire-19 (MSISQ-19) é uma escala de avaliação da disfunção sexual. Objetivo: Adaptar e validar o MSISQ-19 para os pacientes brasileiros com EM. 204 indivíduos foram avaliados, 134 pacientes com EM e 70 controles saudáveis. Foi determinado à reprodutibilidade, validade, consistência interna e a sensibilidade do MSISQ-19BR. Entre os pacientes com EM, 54,3\% dos homens e $71,7 \%$ das mulheres apresentam algum tipo de DS. No grupo controle os resultados foram 12,5\% e 19,5\%, respectivamente. O MSISQ-19BR foi reprodutível, confiável e validade para a população brasileira e pode ser usado como uma ferramenta de avaliação do impacto da disfunção sexual nos pacientes com EM.

Palavras-chave: disfunção sexual, esclerose múltipla, questionários.

Multiple sclerosis (MS) is a chronic inflammatory disease of the central nervous system (CNS) in which demyelination and axonal loss occur in the brain and spinal cord. The disease affects 2.5 million people worldwide. Although the etiology of MS is unknown, there is evidence of genetic predisposition and that some environmental factors may induce an immune system alteration that leads to oligodendrocyte and myelin injury, thus impairing neurotransmission.

The disease course can be slow and progressive, with periods of remission and exacerbation of symptoms, which may include speech and visual disturbances, loss of strength, fatigue, cognitive and emotional disorders, balance and coordination alterations, and also urinary, bowel and sexual problems.

There are four subtypes of MS according to the course of the disease: relapsing-remitting (RRMS), primary progressive (PPMS), secondary progressive (SPMS), and progressive with relapses (RPMS). The available treatments can change the progression of the disease, but special attention should be paid to the diversity of symptoms that may be present.

The quality of life of MS patients is a serious concern. The onset of MS symptoms occurs between 20 and 40 years of age;

Faculdade de Ciências Médicas da Santa Casa de São Paulo, Sao Paulo SP, Brazil.

Correspondence: Guilherme Sciascia do Olival; Faculdade de Ciências Médicas da Santa Casa de São Paulo, Neurologia; Rua Cesário Mota Junior, 112 ; 01221-020 São Paulo SP, Brasil; E-mail: guilhermesolival@gmail.com

Conflict of interest: There is no conflict of interest to declare.

Received 25 January 2015; Received in final form 10 March 2015; Accepted 31 March 2015. 
one of these symptoms, sexual dysfunction (SD), has a striking impact on the lives of patients with MS.

Sexuality is now recognized as one of the major determinants of quality of life in patients with chronic diseases. Sexual satisfaction is considered a relevant variable in assessing social, familial, and affective relations.

Lilius et al. found that SD affects $82 \%-91 \%$ of men and $59 \%-72 \%$ of women with MS compared to $13 \%$ in non-MS subjects ${ }^{1}$. Szasz et al. ${ }^{2}$ found that $50 \%$ of MS patients reported being "concerned" about their sexual life. Lundberg ${ }^{3}$ showed that sexual dysfunction is common even in mild and moderate cases. These percentages are extremely important and should be considered by health professionals when providing a multidimensional treatment.

Sexuality is hard to define. Furthermore, it is a private matter that raises many taboos and involves personal, cultural, and religious factors. In order to understand the effects of MS on sexual functioning, it should be noted that the pathways of sexuality control extend through certain brain centers that receive information from the sense organs and limbic regions and send stimuli to medullary centers that control the effector organs of sexual response. The presence of MS lesions can affect points along the sexual response pathway.

Sexual dysfunction in MS is described according to three basic generating factors: 1) primary, a direct result of neurological injuries involving the genital system itself; 2) secondary, a result of symptoms unrelated to the genital system, or 3) tertiary, a result of cultural and psychosocial issues related to the disease that in some way interfere with sexual function $^{4}$. Despite this categorization, it is very common for patients to have more than one type of SD.

The most common primary dysfunctions in MS are reduction or loss of libido, decreased genital sensitivity, pain or a tingling sensation in the genitals, and difficulty in reaching orgasm. Among men, $\operatorname{Vas}^{5}$ highlights erectile dysfunction, which affects between $60 \%$ and $80 \%$ of patients.

The secondary dysfunctions include spasticity (especially in the lower extremities), fatigue, muscle weakness, urinary and/or fecal incontinence, pain and paresthesia, tremor, shuddering, impaired attention and concentration, and behavioral changes.

Tertiary dysfunctions are mainly related to the social impact of the disease on self-esteem, mood, and personal and professional life. Considering all the above-mentioned factors, it is important to develop an effective survey strategy to elucidate and measure the main impacting features of SD. In a review of sexual function in MS patients, Dupont ${ }^{6}$ determined that one of the biases in studies of sexuality is the limited use of standardized instruments.

The Multiple Sclerosis Intimacy and Sexuality Questionnaire-19 (MSISQ-19), a scale that assesses SD considering the three levels of compromise, was empirically developed as a specific scale to address the multidimensional nature of sexual issues in MS7. The MSISQ-19 was previously used as a tool to evaluate SD in $\mathrm{MS}^{8}$; Foley has recently developed and validated a version with 15 items of the scale based on a large sample of North American patients ${ }^{9}$.

The questionnaire is self-completed and there is a risk that it might be interpreted differently across cultures and populations. Thus, it is recommended that these questionnaires be pre-tested and validated for each population. In this context, the aim of the present study was to adapt and validate the MSISQ-19 to be used as an assessment tool of the impact of sexual dysfunction on Brazilian patients with MS while maintaining the core characteristics of the original version.

The aim of this study was to develop a cross-cultural adaptation and validation of the MSISQ-19 so that it can be used as a tool to evaluate SD in Brazilian patients with MS.

\section{METHOD}

\section{Instrument}

The MSISQ -19 is composed of 19 self-report items measuring the influence of MS symptoms on sexual activity and satisfaction and how they have interfered with the patient's sexual life over the preceding six months. The instrument is divided into three subscales: SD1, for primary sexual dysfunction (items 12, 16, 17, 18, and 19); SD2, secondary (items 1, $2,3,4,5,6,8,10$, and 11), and SD3, tertiary (items 7, 9, 13, 14, and 15). Each item is rated from 1-5 based on the Likert scale ( 1 = never; 2 = seldom; 3 = sometimes; 4 = often, and 5 = always); a final score is generated by the summation of the scores across items. The higher the score, the greater the impact of SD on patients' lives ${ }^{10}$.

The Expanded Disability Status Scale (EDSS) is a 10-point scale typically employed to assess the progression of MS-related disability. The scale has 20 levels of clinical impairment graded in 0.5 increments, with 0 (zero) being the best score (normal neurological examination) and 10 the worst (death from MS) ${ }^{11}$.

\section{Translation and cultural adaptation}

The cross-cultural adaptation and validation protocols were followed according to specialized literature ${ }^{12}$. Initially, the items of the English version were translated into Portuguese by two independent English teachers who were aware of the objective of the study. These two translations were compared and modifications were made until consensus was reached. The consensus translation was back-translated into English by a native English teacher who had not participated in the previous step. The back-translated English version and the original questionnaires were compared and no significant discrepancies were noted.

A pilot study was carried out for pre-test analysis of cultural equivalence. The scale was applied to a group of $11 \mathrm{MS}$ patients without cognitive impairment selected randomly 
at the Centre of Care and Treatment of Multiple Sclerosis (CATEM) at the Santa Casa de Misericórdia de São Paulo. The purpose of this procedure was to identify issues that were not understood by the population and therefore were deemed culturally inappropriate; however, no question fit those parameters. Thus, the final versions of the Portuguese language scale, named MSISQ-19-BR, were generated.

\section{Subjects}

In all, 134 patients with MS, including 99 women and 35 men, were selected. The control group comprised 70 non-MS subjects, with 46 females and 24 males. The patients with MS were randomly selected among those being treated at the CATEM.

The inclusion criteria was a confirmed diagnosis of MS according to the revised McDonald criteria 2010 and the absence of other pathological conditions that might lead to SD, such as psychological disorders, abnormal hormonal activity, vaginismus, previous erectile dysfunction, sexual arousal disorders and use of specific medication, among others. Participants were excluded if they were undergoing an MS outbreak. All subtypes of MS were included, trying to respect the prevalence proportion. The 70 non-MS subjects were randomly selected among accompanying of patients with MS at the CATEM and of other patients with other conditions being treated at the same hospital. The exclusion criteria for the control group were having MS or any other pathology that might cause SD.

All subjects were informed about the purpose of the study and provided written informed consent.

The MSISQ-19 questionnaire was administered in a quiet and private environment to minimize possible constraints. Data regarding gender, age, level of education, disease duration and MS subtype, neurological examination, and EDSS score were collected. After 30 days, the same researchers gave a retest with 48 patients to analyze the stability and reliability of the scale.

\section{Statistical analysis}

Descriptive analysis was done based on the frequency of categorical variables and measures of position and dispersion of continuous variables. A multivariate analysis of variance was performed for gender, age, level of education, disease duration, and EDSS score to identify extraneous variables. The results were analyzed and compared between the control group and patients with MS in order to clarify the significance of the final score.

To validate the instrument, we followed the standards proposed by Instrument Review Criteria (SAC) and assessed reliability, validity, and sensitivity ${ }^{13,14}$. The reliability of the questionnaire was assessed based on internal consistency and test-retest stability, obtained respectively by Cronbach's alpha and Pearson's correlation coefficients. The validity of the instrument was determined by comparing the results of the MSISQ-19-BR with the EDSS scores using Pearson's correlation coefficient. The sensitivity of the scale was established by comparing the results of four different groups: control group with and without SD; MS patients with and without SD. This subdivision allowed an evaluation of the ability of the scale to identify each of these four groups using the Mann-Whitney and Kruskal-Wallis tests ${ }^{15}$.

The level of significance was set at $\mathrm{p}=0.05$ for all statistical tests. The statistical analyses were conducted with the aid of the Statistical Package for Social Sciences (SPSS) version 17.0.

\section{RESULTS}

We evaluated 204 individuals: 70 in the control group and 134 patients with MS. The socio-demographic and clinical data are shown in Table 1 . The multivariate analysis of variance showed that gender, age, and level of education did not affect the results of the test and retest nor the subsequent analysis.

Among the patients with MS, $54.3 \%$ of the male individuals and $71.7 \%$ of the female exhibited some degree of SD, defined as a score greater than 30 or any response 4 (often) or 5 (always). For the control group, the results were $12.5 \%$ and $19.5 \%$, respectively. The means and standard deviations for the SD1, SD2 and SD3 subscales and the total score of the MS group were compared between male and female subjects (Table 2).

The internal consistency for the subscales (SD1, SD2 and SD3) and between the 19 questions in MSISQ-19-BR was assessed using Cronbach's alpha coefficient for all subjects and individually for each group. These results are shown in Table 3.

A high level of reproducibility was found, with $86.76 \%$ of concordance between the studied behaviors. The

Table 1. Socio-demographic and clinical data of the control group and the MS group.

\begin{tabular}{|c|c|c|}
\hline Socio-demographic data & Control group $(n=70)$ & MS group $(n=134)$ \\
\hline Gender F:M & $41 \mathrm{~F}: 29 \mathrm{M}$ & $99 F: 35 M$ \\
\hline Age & $41.37(14.59)$ & $41.34(11.88)$ \\
\hline School index (\% with high school) & $77.1 \%$ & $79.9 \%$ \\
\hline Disease duration & & $6.54(6, .77)$ \\
\hline EDSS & & 3.18 (2.18) \\
\hline
\end{tabular}

Data are presented as mean +/-SD. SD: standard deviation; F: female; M: male; MS: multiple sclerosis; EDSS: Expanded Disability Status Scale. 
average scores for the test and retest were 35.15 and 35.40 , respectively. The correlation between outcomes in the test and retest as assessed by Pearson's correlation coefficient showed a strong association, with a value of more than 0.90 and $\mathrm{p}<0.001$.

Validity was determined by an evaluation of the behavior domains of the MSISQ-19-BR depending on the extent of EDSS, also using Pearson's correlation. Although other studies have demonstrated an association between the EDSS score and $\mathrm{SD}^{16}$, no significant correlations were observed in our study, which is consistent with the results of the study by Tzortzis et al. ${ }^{17}$.

Sensitivity is a measure of the ability of a scale to distinguish groups with different characteristics. The study subjects were divided into four groups (control and MS, with or without SD) and the scores were compared using the Mann-Whitney and Kruskal-Wallis tests. The results are shown in Tables 4 and 5.

\section{DISCUSSION}

Sexual satisfaction is considered a relevant variable in quality of life assessments. Problems with sexual function are common in patients suffering from degenerative and disabling diseases.

Table 2. Parallel between women and men of the MS group.

\begin{tabular}{lcc}
\hline Aspect & Women $(n=99)$ & Men $(n=35)$ \\
\hline SD1 & $12.29(6.42)$ & $9.22(4.83)$ \\
SD2 & $19.80(9.02)$ & $18.14(8.27)$ \\
SD3 & $11.11(6.17)$ & $9.54(5.72)$ \\
Total & $43.21(19.77)$ & $36.91(17.09)$ \\
\hline
\end{tabular}

SD1: Sexual Dysfunction Primary; SD2: Sexual Dysfunction Secundary; SD3: Sexual Dysfunction Tertiary; MS: multiple sclerosis.

Table 3. Internal consistency given by Cronbach's alpha coefficient.

\begin{tabular}{lcc}
\hline Cronbach's alpha & $\begin{array}{c}\text { For subscales } \\
\text { (DS1, DS and DS3) }\end{array}$ & $\begin{array}{c}\text { For questions } \\
\text { (1 to 19) }\end{array}$ \\
\hline All subjects & 0.898 & 0.955 \\
Control group & 0.870 & 0.918 \\
MS group & 0.879 & 0.945 \\
\hline
\end{tabular}

MS: Multiple Sclerosis; SD1: Sexual Dysfunction Primary; SD2: Sexual Dysfunction Secundary; SD3: Sexual Dysfunction Tertiary.

Zorzon et al. ${ }^{18}$ reported that the incidence of SD in patients with MS (73\%) is higher than in people with chronic diseases (39\%) and in the general population (13\%). The incidence of SD in our study was approximately $72 \%$ in women and $54 \%$ in men. Other studies have found incidence rates ranging from $50 \%$ to more than $70 \%$. In a study by Lilius et al. ${ }^{1}, 64 \%$ of men and $39 \%$ of women described their sex life as "unsatisfactory". Sexual dysfunction seems to be affected by the level of disability and disease duration, but the impact of those factors remains unclear. Hulter and Lundberg noted that $90 \%$ of MS patients using wheelchairs have "big problems with sexual function" ${ }^{19}$, which need to be properly addressed.

Patients with MS have high levels of SD and their partners also show less satisfaction with their sex lives and relationships. How patients react to the perception of their disease by others impacts their sexual behavior.

If the patient with MS becomes unable to engage in sexual activity, the partner and the whole family dynamics can be affected. Sexual satisfaction is frequently associated with acceptance, trust, and communication. Therefore, SD should not be treated as a single somatic disorder; rather, it should also be seen in its cognitive and emotional aspects, thus helping patients to find a new path in their sex lives.

Most researchers suggest that MS has a negative impact on relationships and satisfaction with the romantic relationship is lower than in the general population ${ }^{20,21,22}$. Health professionals should be aware of the high rates of SD and low levels of sexual satisfaction among individuals with MS. Nevertheless, it is estimated that $94 \%$ of MS patients have never been questioned about their sexuality ${ }^{21}$. Disorders related to sexuality are often pushed into low priority by health professionals, especially because of the difficulties in effectively approaching this subject and the lack of more specialized information. Patients often feel uncomfortable and

Table 5. Sensitivity analysis of MSISQ-19-BR and control groups MS.

\begin{tabular}{lcc}
\hline Aspect & Mann-Whitney U & Significance $(p)$ \\
\hline SD1 & 2016.00 & $p<0.0001$ \\
SD2 & 1431.50 & $p<0.0001$ \\
SD3 & 1871.00 & $p<0.0001$ \\
Total & 1297.50 & $p<0.0001$ \\
\hline MSISQ-19: Multiple Sclerosis Intimacy & and Sexuality Questionnaire-19; \\
SD1: Sexual Dysfunction Primary; SD2: Sexual Dysfunction Secundary; \\
SD3: Sexual Dysfunction Tertiary.
\end{tabular}

Table 4. Sensitivity analysis of MSISQ-19-BR and control groups MS, with and without SD.

\begin{tabular}{lccccc}
\hline Aspect & Control without SD $(n=58)$ & Control with SD $(n=12)$ & MS without SD $(n=44)$ & MS with SD $(n=90)$ & Significance $(p)$ \\
\hline SD1 & $5.46(1.18)$ & $11.58(5.99)$ & $6.40(2.04)$ & $13.97(6.00)$ & $p<0.0001$ \\
SD2 & $9.60(1.41)$ & $15.91(5.35)$ & $11.18(2.49)$ & $23.37(8.01)$ & $p<0.0001$ \\
SD3 & $5.17(0.56)$ & $8.00(3.30)$ & $5.50(0.95)$ & $13.24(5.90)$ & $p<0.0001$ \\
Total & $22.55(7.80)$ & $24.33(9.50)$ & $23.09(3.38)$ & $50.60(17.22)$ & $p<0.0001$ \\
\hline
\end{tabular}

Data are presented as mean +/-SD. MSISQ-19: Multiple Sclerosis Intimacy and Sexuality Questionnaire-19; SD: standard deviation; MS: multiple sclerosis; SD1: Sexual Dysfunction Primary; SD2: Sexual Dysfunction Secundary; SD3: Sexual Dysfunction Tertiary. 
unable to speak about their sexuality, but most of them believe it to be appropriate to address sexual functioning in routine office visits ${ }^{23}$.

Previous studies have demonstrated that sexual counseling is helpful ${ }^{24}$; educational materials and conversations about sexual problems in MS also seemed beneficial ${ }^{25}$. In providing care, it is important for the health professional to find a balance between distance and intimacy, allowing patients to address their sexual issues without judgment. First of all, the physician should perform a complete evaluation and determine what type of SD the patient manifests and whether it appeared before or after the onset of MS symptoms.

Treatment of any SD begins with information provided to patients; however, other factors should be considered, such as the etiology of the disorder, the patient's age, sexual experience, and whether the patient and partner are in a steady relationship. Bronner et al. ${ }^{26}$ suggested some interventions that could minimize the impact of SD: hormone administration, treatment of underlying conditions (e.g., depression, urinary incontinence), and masturbation, among others.

Therapy starts when the physician shows concern about the patient's sex life. It is important to consider that, despite the high prevalence of SD in MS, other conditions should not be neglected, such as hypertension, diabetes, incontinence, psychiatric disorders, and side effects of drugs ${ }^{27}$. Assessing the prevalence and cause of sexual problems that may require clinical intervention is essential.
Depression, for example, is highly prevalent in MS patients $^{28,29}$. The feeling of dependence related to depressive episodes can also cause decreased sexual drive. The fear of being rejected sexually, the feeling of being less attractive, communication difficulties, fear of isolation and abandonment, guilt, and the impact of the disease on the partner-especially when he or she becomes the caregiver-are some of the prominent issues.

In this context, some areas related to sexual behavior should be explored: responsiveness to sexual stimulation, motor difficulties, hygiene aspects, urinary and fecal incontinence, fertility, libido, communication with partners, and prospects for sex life. Considering all the aspects that have been discussed, the present study confirms the need to address sexuality in MS patients. The use of a standardized tool can facilitate the initial approach and introduce the topic in a non-threatening way in clinical practice.

In conclusion, the MSISQ-19-BR is a reproducible, reliable, and valid instrument for the Brazilian population. It also showed easy clinical applicability and can be used in the day-to-day care of patients with MS. The administration of a standardized instrument can facilitate the initial approach and introduce the theme of sexuality in regular physician office visits. Therefore, the MSISQ-19-BR is a valuable tool to help physicians and patients in addressing this sensitive subject and to enable a multidimensional treatment, thereby improving the quality of life of MS patients.

\section{References}

1. Lilius HG, Valtonen EJ, Wikström J. Sexual problems in patients suffering from multiple sclerosis. J Chronic Dis. 1976;29(10):643-7. http://dx.doi.org/10.1016/0021-9681(76)90021-7

2. Szasz G, Paty D, Lawton-Speert S, Eisen K. A sexual functioning scale in multiple sclerosis. Acta Neurol Scand Suppl. 1984;101:37-43. http://dx.doi.org/10.1111/j.1600-0404.1984.tb02550.x

3. Lundberg PO. Sexual dysfunction in patients with multiple sclerosis. Sex Disabil. 1978;1(3):218-22. http://dx.doi.org/10.1007/BF01101328

4. Schmidt EZ, Hofmann P, Niederwieser G, Kapfhammer HP, Bonelli RM. Sexuality in multiple sclerosis. J Neural Transm. 2005;112(9):1201-11. http://dx.doi.org/10.1007/s00702-005-0275-7

5. Vas CJ.Sexual impotence and some autonomic disturbances in men with multiple sclerosis. Acta Neural Scand. 1969;45(2):166-82. http://dx.doi.org/10.1111/j.1600-0404.1969.tb01230.x

6. Dupont S. Sexual function and ways of coping in patients with multiple sclerosis and their partners. J Sex Marital Ther. 1996;11(4):359-72. http://dx.doi.org/10.1080/02674659608404450

7. McCabe MP. Sexual dysfunction scale. In: Davis CM, Yarber WL, Bauserman R, Schreer G, Davis SL, editors. Handbook of sexuality-related measures. Thousand Oaks: Sage; 1998. p. 191-2

8. Demirkiran M, Sarica Y, Uguz S, Yerdelen D, Aslan K. Multiple sclerosis patients with and without sexual dysfunction: are there any differences? Mult Scler. 2006;12(2):209-14. http://dx.doi.org/10.1191/135248506ms1253oa

9. Foley FW, Zemon V, Campagnolo D, Marrie RA, Cutter G, Tyry T et al. The Multiple Sclerosis Intimacy and Sexuality Questionnaire: re-validation and development of a 15-item version with a large US sample. Mult Scler. 2013;19(9):1197-203. http://dx.doi.org/10.1177/1352458512471876

10. Sanders AS, Foley FW, LaRocca NG, Zemon V. The Multiple Sclerosis Intimacy and Sexuality Questionnaire-19 (MSISQ-19). Sex Disabil. 2000;18(1):3-26. http://dx.doi.org/10.1023/A:1005421627154

11. Kurtzke JF. Rating neurologic impairment in multiple sclerosis: an expAnded disability status scale (EDSS). Neurology. 1983;33(11):1444-52. http://dx.doi.org/10.1212/WNL.33.11.1444

12. Beaton DE, Bombardier C, Guillemin F, Ferraz MB. Guidelines for the process of cross-cultural adaptation of self-report measures. Spine. 2000;25(24):3186-91. http://dx.doi.org/10.1097/00007632-200012150-00014

13. Franzen MD. Reliability and validity in neuropsychological assessment. New York: Plenum Publishers, 2000, 465p. Assessing health status and quality of life instruments: atributes and review criteria. Qual Life Res. 2002;11(3):193-205. http://dx.doi.org/10.1023/A:1015291021312

14. Lohr KN, Aaronson NK, Alonso J, Burnam MA, Patrick DL, Perrin EB et al. Evaluating quality-of-life and health status instruments: development of scientific review criteria. Clin Ther. 1996;18(5):979-92. http://dx.doi.org/10.1016/S0149-2918(96)80054-3

15. McDowelL I. Measuring health: a guide to rating scales and questionnaires. 3rd ed. New York: Oxford University Press; 2006.

16. Hulter BM, Lundberg PO. Sexual function in women with advanced multiple sclerosis. J Neurol Neurosurg Psychiatry. 1995;59(1):83-6. http://dx.doi.org/10.1136/jnnp.59.1.83 
17. Tzortzis V, Skriapas K, Hadjigeorgiou G, Mitsogiannis I, Aggelakis K, Gravas S et al. Sexual dysfunction in newly diagnosed multiple sclerosis women. Mult Scler. 2008;14(4):561-3. http://dx.doi.org/10.1177/13524585080140040901

18. Zorzon M, Zivadinov R, Bosco A, Bragadin LM, Moretti R, Bonfigli L et al. Sexual dysfunction in multiple sclerosis: a case-control study. I. Frequency and comparison of groups. Mult Scler. 1999;5(6):418-27. http://dx.doi.org/10.1177/135245859900500i609

19. Hulter BM, Lundberg PO. Sexual function in women with advanced multiple sclerosis. J Neurol Neurosurg Psychiatry. 1995;59(1):83-6.

20. Kessler TM, Fowler CJ, Panicker JN. Sexual dysfunction in multiple sclerosis. Expert Rev Neurother. 2009;9(3):341-50. http://dx.doi.org/10.1586/14737175.9.3.341

21. McCabe MP, McDonald E, Deeks AA, Vowels LM, Cobain MJ. The impact of multiple sclerosis on sexuality and relationships. J Sex Res. 1996;33(3):241-8. http://dx.doi.org/10.1080/00224499609551840

22. Hakim EA, Bakheit AMO, Bryant TN, Roberts MWH, Mclntosh-Michaelis SA, Spackman AJ et al. The social impact of multiple sclerosis: a study of 305 patients and their relatives. Disabil Rehabil. 2000;2(6)2:288-93. http://dx.doi.org/10.1080/096382800296755

23. Vermillion S, Holmes M. Sexual dysfunction in women. PrIm Care Update Ob Gyns. 1997;4(6):234-40. http://dx.doi.org/10.1016/S1068-607X(97)00104-2
24. Stenager E, Stenager EN, Jensen K. Sexual aspects of multiple sclerosis. Semin Neurol. 1992;12(2):120-4. http://dx.doi.org/10.1055/s-2008-1041165

25. Christopherson JM, Moore K, Foley FW, Warren KG. A comparison of written materials vs. materials and counselling for women with sexual dysfunction and multiple sclerosis. J Clin Nurs. 2006;15(6):742-50. http://dx.doi.org/10.1111/j.1365-2702.2005.01437.x

26. Bronner G, Elran E, Golomb J, Korczyn AD. Female sexuality in multiple sclerosis: the multidimensional nature of the problem and the intervention. Acta Neurol Scand. 2010;121(5):289-301. http://dx.doi.org/10.1111/j.1600-0404.2009.01314.x

27. Shifren JL, Monz BU, Russo PA, Segreti A, Johannes CB. Sexual problems and distress in United States women: prevalence and correlates. Obstet Gynecol. 2008;112(5):970-8. http://dx.doi.org/10.1097/AOG.0b013e3181898cdb

28. Fruehwald S, Loeffler-Stastka H, Eher R, Saletu B, Baumhackl U. Depression and quality of life in multiple sclerosis. Acta Neurol Scand. 2001;104(5):257-61. http://dx.doi.org/10.1034/j.1600-0404.2001.00022.x

29. Patten SB, Beck CA, Williams JV, Bardui C, Metz LM. Major depression in multiple sclerosis: a population-based perspective. Neurology. 2003;61(11):1524-7. http://dx.doi.org/10.1212/01.WNL.0000095964.34294.B4

\section{ANNEX}

\section{Multiple Sclerosis Intimacy and Sexuality Questionnaire-19 [MSISQ-19]}

\section{Instructions}

In order to better understand the impact of multiple sclerosis (MS) on intimacy and sexuality, this 19-item questionnaire asks you to rate how various MS symptoms have interfered with your sexual activity or satisfaction over the last six months. Questions may be answered by placing a check or any other mark in the square located next to the question and below the appropriate number. There are no right or wrong answers. If you are unsure how to answer a question, please choose the best answer you can.

\begin{tabular}{|c|c|c|c|c|c|}
\hline \multirow{2}{*}{$\begin{array}{l}\text { Over the last six months, the following symptoms have } \\
\text { interfered with my sexual activity or satisfaction: }\end{array}$} & Never & Almost Never & Occasionally & Almost Always & Always \\
\hline & 1 & 2 & 3 & 4 & 5 \\
\hline \multicolumn{6}{|l|}{ 1. Muscle tightness or spasms in my arms, legs, or body } \\
\hline \multicolumn{6}{|l|}{ 2. Bladder or urinary symptoms } \\
\hline \multicolumn{6}{|l|}{ 3. Bowel symptoms } \\
\hline \multicolumn{6}{|l|}{ 4. Feelings of dependency because of MS } \\
\hline \multicolumn{6}{|l|}{ 5. Tremors or shaking in my hands or body } \\
\hline \multicolumn{6}{|l|}{ 6. Pain, burning, or discomfort in my body } \\
\hline \multicolumn{6}{|l|}{ 7. Feeling that my body is less attractive } \\
\hline \multicolumn{6}{|l|}{ 8. Problems moving my body the way I want during sexual activity } \\
\hline \multicolumn{6}{|l|}{ 9. Feeling less masculine or feminine due to MS } \\
\hline \multicolumn{6}{|l|}{ 10. Problems with concentration, memory, or thinking } \\
\hline \multicolumn{6}{|l|}{ 11. Exacerbation or significant worsening of my MS } \\
\hline \multicolumn{6}{|l|}{ 12. Less feeling or numbness in my genitals } \\
\hline \multicolumn{6}{|l|}{ 13. Fear of being rejected sexually because of MS } \\
\hline \multicolumn{6}{|l|}{ 14. Worries about sexually satisfying my partner } \\
\hline \multicolumn{6}{|l|}{ 15. Feeling less confident about my sexuality due to MS } \\
\hline \multicolumn{6}{|l|}{ 16. Lack of sexual interest or desire } \\
\hline \multicolumn{6}{|l|}{ 17. Less intense or pleasurable orgasms or climaxes } \\
\hline \multicolumn{6}{|l|}{ 18. Takes too long to orgasm or climax } \\
\hline $\begin{array}{l}\text { 19. Inadequate vaginal wetness or lubrication (women)/ } \\
\text { difficulty getting or keeping a satisfactory erection (men) }\end{array}$ & & & & & \\
\hline
\end{tabular}




\section{Scoring:}

Primary sexual dysfunction

items $=12,16,17,18,19$

Secondary sexual dysfunction

items $=1,2,3,4,5,6,8,10,11$

Tertiary sexual dysfunction

items $=7,9,13,14,15$

Any item scoring "4" or "5" should be discussed with your MS health care provider.

\section{Escala sobre intimidade e sexualidade na esclerose múltipla}

\section{Instruções}

Para melhor entender o impacto da esclerose múltipla (EM) na intimidade e sexualidade, este questionário com 19 itens pede para você classificar como os diversos sintomas da EM tem interferido na sua atividade sexual ou na sua satisfação sexual nos últimos seis meses. As questões podem ser respondidas através de uma marcação no quadrado localizado ao lado da questão e abaixo do número que correspondente a sua resposta. Não existe resposta certa ou errada. Caso você não tenha certeza de como responder a pergunta, por favor, escolha a me- lhor resposta que você puder.

\begin{tabular}{|c|c|c|c|c|c|}
\hline \multirow{2}{*}{$\begin{array}{l}\text { Nos últimos seis meses, os sintomas abaixo têm interferido na } \\
\text { minha atividade sexual e satisfação sexual: }\end{array}$} & Nunca & Quase nunca & Ocasionalmente & Quase sempre & Sempre \\
\hline & 1 & 2 & 3 & 4 & 5 \\
\hline \multicolumn{6}{|l|}{ 1. Rigidez muscular nos meus braços, pernas ou corpo } \\
\hline \multicolumn{6}{|l|}{ 2. Sintomas de incontinência urinária } \\
\hline \multicolumn{6}{|l|}{ 3. Sintomas no intestino } \\
\hline \multicolumn{6}{|l|}{ 4. Sentimentos de dependência por causa da EM } \\
\hline \multicolumn{6}{|l|}{ 5. Tremores ou agitações em minhas mãos e corpo } \\
\hline \multicolumn{6}{|l|}{ 6. Dor, queimação ou desconforto em meu corpo } \\
\hline \multicolumn{6}{|l|}{ 7. Sentimento de que meu corpo é menos atrativo } \\
\hline \multicolumn{6}{|l|}{$\begin{array}{l}\text { 8. Problemas movendo meu corpo do jeito que eu quero durante a } \\
\text { atividade sexual }\end{array}$} \\
\hline \multicolumn{6}{|l|}{ 9. Sentindo-me menos masculino ou feminino devido a EM } \\
\hline \multicolumn{6}{|l|}{ 10. Problemas de concentração, memória ou pensamentos } \\
\hline \multicolumn{6}{|l|}{ 11. Exacerbação ou significante agravamento da minha EM } \\
\hline \multicolumn{6}{|l|}{ 12. Menor sensibilidade ou entorpecimento das minhas genitais } \\
\hline \multicolumn{6}{|l|}{ 13. Medo de ser rejeitado sexualmente por causa da EM } \\
\hline \multicolumn{6}{|l|}{ 14. Preocupações a respeito da satisfação sexual do meu parceiro } \\
\hline \multicolumn{6}{|l|}{$\begin{array}{l}\text { 15. Sentindo-me menos confiante sobre minha sexualidade } \\
\text { devido à EM }\end{array}$} \\
\hline \multicolumn{6}{|l|}{ 16. Falta de desejo ou interesse sexual } \\
\hline \multicolumn{6}{|l|}{ 17. Orgasmo ou clímax menos intensos e/ou menos prazerosos } \\
\hline \multicolumn{6}{|l|}{ 18. Demora ao orgasmo ou clímax } \\
\hline $\begin{array}{l}\text { 19. Lubrificação e umidade vaginal inadequada (mulher)/ } \\
\text { dificuldade de obter ou manter ereção satisfatória (homem) }\end{array}$ & & & & & \\
\hline
\end{tabular}

